\title{
SOME MINERALOGICAL AND GEOCHEMICAL ASPECTS OF CHROMIUM-BEARING SKARN MINERALS FROM NORTHERN KARELIA, FINLAND
}

\author{
OLEG VON KNORRING; ERIC CONDLIFFE and Y. L. TONG
}

\begin{abstract}
VON KNORRING, O.; CONDLIFFE, E. and TONG, Y. L., 1986: Some mineralogical and geochemical aspects of chromium-bearing skarn minerals from northern Karelia, Finland. Bull. Geol. Soc. Finland 58, Part 1, 277-292.

The chromiferous skarn mineral associations at Outokumpu have been described and a number of characteristic chromium-bearing minerals have been re-examined. A large number of wet chemical and microprobe analyses are presented for zincian chromite, uvarovite, chromian diopside, chromian tremolite, eskolaite and chromian clinozoisite. In the course of this study a vanadian uvarovite and a vanadianzincian chromite have been noted.
\end{abstract}

Key words: zincian chromite, uvarovite, skarn, Outokumpu, Finland.

Oleg von Knorring and Eric Condliffe: Department of Earth Sciences, The University, Leeds LS2 9JT, U.K.

Y. L. Tong: Geological Survey, P.O. Box 1015, Ipoh, Malaysia.

\section{Introduction}

The remarkable, chromium-bearing skarn mineralization associated with the copper deposit at Outokumpu and some other closely related ore occurrences in northern Karelia in Finland have for many years attracted great interest.

The first account of the chromium garnet uvarovite, from Outokumpu (Kuusjärvi) was given by Borgström in 1901, some nine years before the extensive copper-ore deposit was discovered. During the past fifty years a number of rare chromium minerals and among them some new mineral species and varieties have been described by Eskola (1933), von Knorring (1951), Vähätalo (1953), Kouvo and Vuorelainen (1958), Thayer et al. (1964), Tong (1966), Peltola et al. (1968), and Vuorelainen et al. (1968).

In this study, some additional mineralogical and chemical data on the interesting suite of chromium minerals from the Outokumpu region will be presented.

\section{Geological setting}

The geology of the mineralized Outokumpu region has been admirably described by a number of authors e.g. Haapala (1936), Väyrynen (1939), Vähätalo (1953) and in recent years by Huhma and Huhma (1970).

The copper-nickel-cobalt mineralization at $\mathrm{Ou}-$ 
tokumpu is found within an extensive belt of quartzitic rocks associated with large, often lensoid bodies of serpentinite, layers of chromiferous skarns and dolomitic rocks set in a country rock of mica schists, which in the proximity of the ore complex are frequently carbonaceous black schists.

A characteristic feature of this ore deposit is the intimate association of serpentinites with the quartzites. The former are considered to have been derived from original dunites, including some pyroxenitic and peridotitic varieties, whereas the quartzitic rocks appear to have been silica precipitates formed through the action of intruding ultramafic magma, serpentinization and carbonatization and ultimately metamorphosed into rocks resembling quartzites (Huhma and Huhma 1970).

\section{Skarn rocks}

A distinct feature of the Outokumpu ore field is the extensive skarn mineralization and, in particular, the unique occurrence of chromiferous varieties of skarn minerals in great abundance. The serpentinites, are according to Peltola et al. (1968), commonly enveloped by a dolomitic halo of variable thickness and the skarns are located between the dolomite and the quartzite. The serpentinites grade into quartzites through the following sequence: serpentinite, dolomite, tremolitic dolomite, tremolite skarn, diopside skarn and quartzite. Typically, the quartzites themselves carry variable amounts of chromiferous calc-silicates, predominantly diopside with some tremolite, uvarovite and other minerals in narrow bands, parallel to the schistosity. The skarn zones vary from a few $\mathrm{cm}$ to several tens of metres. Huhma (1970), records skarn formations up to $35 \mathrm{~m}$ wide and over $3 \mathrm{~km}$ long. These skarns differ on mineralogical and geochemical grounds from those of the epi-continental facies elsewhere in the region, in that feldspar and biotite are absent and the contents of chromium and nickel are some twenty times higher in the Outokumpu skarns. Eskola (1933) has given an excellent account of the occurrence of chromium minerals from Outokumpu and presented a number of mineral analyses. He also drew attention to the concentration of chromium in the serpentinites and to the various chromium mineral associations in the area, e.g.,:

1. Chromian muscovite (fuchsite) in the quartzites, which also contain chromian diopside, chromian tremolite and uvarovite.

2. Skarns of uvarovite, chromian diopside and chromian tremolite associated with dolomite.

3. Occurrence of chromite in a dolomitic rock.

4. Chromian spinel (picotite), chromite, chromian clinochlore (kämmererite), anthophyllitecordierite rocks.

5. Uvarovite, chromian epidote (tawmawite) with some chromite in quartz-bearing copper ore.

6. Veins carrying uvarovite, chromian epidote, chromian tremolite, sulphides, mostly pyrrhotite with some minor chromian diopside and chromite.

For this contribution, some of the chromium minerals, eskolaite, uvarovites and spinels, in particular, have been re-examined in some detail by microprobe. In addition, a number of new wet chemical analyses of the major chromiferous skarn minerals are presented.

Microprobe analyses were made using a Link 860 series 2 energy dispersive system fitted to a Jeol JXA-500 electron microprobe; accelerating voltage, $20 \mathrm{kV}$; beam current, 1 nanoamp; live time, 100 seconds. Standards used were: $\mathrm{Si}$ and $\mathrm{Ca}$ - wollastonite; $\mathrm{Na}$ - jadeite; $\mathrm{K}$ - orthoclase; $\mathrm{Mn}$ - rhodonite; $\mathrm{Fe}$ - haematite; $\mathrm{Mg}, \mathrm{Al}$ and $\mathrm{Ti}$ - pure oxides; $\mathrm{V}, \mathrm{Cr}$ and $\mathrm{Ni}$ - pure metals. Total $\mathrm{Fe}$ was calculated as $\mathrm{Fe}^{2+}$ for all phases other than garnet and eskolaite, where $\mathrm{Fe}^{3+}$ was used. Garnet end-member calculations were made on-line following the procedure of Rickwood (1968), but omitting the calculation of the rarer species. Goldmanite (the Ca:V molecule) was retained in the calculation sequence to 
allow for the small but ubiquitous presence of vanadium in the analyses. Percentage cation allocations were $>97 \%$ and usually better than $98 \%$.

\section{Chromites}

A brownish, zincian chromite is a rather conspicuous accessory mineral, particularly in the chromiferous skarn rocks at Outokumpu. This mineral is frequently seen in the uvarovite-rich skarns as speckles and rounded mm sized grains. Occasionally it is observed in stringers and veinlets or larger accumulations and most commonly as tiny, corroded inclusions in the centre of uvarovite crystals, as observed by one of us (O. v. K. 1951), Vähätalo (1953) and Weiser (1967).

Vähätalo (1953) noted, moreover, spectacular dykelets of chromite, up to $15 \mathrm{~mm}$ wide, intersecting the diopside skarns, thus indicating a secondary hydrothermal origin of this particular chromite.
The precise composition of the zincian chromite was, however, not known until Thayer et al. (1964) published their study of this unusual mineral.

Subsequent research by one of us (Y.L.T. 1966) showed that the zincian chromite occurring in the skarn rocks is often rather inhomogenous and porous, and is seen to contain a variety of minute inclusions, which makes the purification of the mineral for chemical analysis exceedingly difficult. In Table 1 the two wet chemical analyses of zincian chromite are compared with the analysis by Thayer et al., and with the present microprobe results of a similar chromite. Eskola (1933) described an unusual occurrence of chromite in a calc-silicate-bearing dolomite from Raivionmäki within the Outokumpu area, and indicated, that if the dolomite is assumed to have been the product of metasomatic replacement of an ultrabasic rock, it would be easy to understand that the chromite phenocrysts may be relicts of the primary chromite phase, which settled together with the olivine.

Table 1. Chemical composition and physical properties of zincian chromites from Outokumpu.

\begin{tabular}{|c|c|c|c|c|c|c|c|c|}
\hline & 1 & 2 & 3 & 4 & 5 & 6 & 7 & 8 \\
\hline $\mathrm{SiO}_{2}$ & 3.02 & 2.09 & 2.8 & 0.27 & 0.37 & 0.19 & 0.22 & 0.53 \\
\hline $\mathrm{TiO}_{2}$ & 0.06 & 0.05 & 0.1 & 0.10 & 0.00 & 0.09 & 0.04 & 0.30 \\
\hline $\mathrm{Al}_{2} \mathrm{O}_{3}$ & 6.16 & 4.37 & 7.4 & 7.26 & 4.93 & 7.56 & 6.03 & 8.76 \\
\hline $\mathrm{Cr}_{2} \mathrm{O}_{3}$ & 58.75 & 63.55 & 54.0 & 60.19 & 62.62 & 60.11 & 62.07 & 57.51 \\
\hline $\mathrm{V}_{2} \mathrm{O}_{3}$ & - & - & - & 0.16 & 0.01 & 0.11 & 0.08 & 0.16 \\
\hline $\mathrm{Fe}_{2} \mathrm{O}_{3}$ & nil & nil & 3.0 & - & - & - & - & - \\
\hline $\mathrm{FeO}$ & 24.30 & 21.53 & 17.1 & 19.19 & 18.53 & 17.76 & 18.56 & 16.67 \\
\hline $\mathrm{MnO}$ & 1.20 & 1.59 & 2.0 & 3.70 & 4.81 & 3.56 & 4.05 & 4.00 \\
\hline $\mathrm{MgO}$ & 2.83 & 5.19 & 4.3 & 1.43 & 1.46 & 2.08 & 1.60 & 2.02 \\
\hline $\mathrm{ZnO}$ & 2.11 & 0.49 & 5.8 & 7.69 & 7.64 & 8.74 & 7.55 & 9.40 \\
\hline $\mathrm{NiO}$ & - & - & - & 0.08 & 0.00 & 0.04 & 0.00 & 0.00 \\
\hline $\mathrm{CaO}$ & 0.80 & 0.96 & 0.54 & 0.00 & 0.09 & 0.07 & 0.01 & 0.35 \\
\hline $\mathrm{H}_{2} \mathrm{O}+$ & 1.01 & 0.68 & 1.55 & - & - & - & - & - \\
\hline $\mathrm{H}_{2} \mathrm{O}-$ & 0.18 & 0.10 & - & - & - & - & - & - \\
\hline Total & 100.42 & 100.50 & 98.59 & 100.07 & 100.46 & 100.31 & 100.21 & 99.70 \\
\hline D & 4.02 & 4.66 & - & & & & & \\
\hline a & $8.3416 \AA$ & $8.3364 \AA$ & $8.345 \AA$ & & & & & \\
\hline
\end{tabular}

1. Chromite in diopside-tremolite-sulphide skarn, analyst: Y. L. Tong.

2. Chromite in uvarovite-diopside-tremolite-sulphide skarn, analyst: Y. L. Tong.

3. Chromite from a chromite dykelet, analyst: J. Dinnin and H. Rose.

4-8. Microprobe analyses of chromite from a chromite band in uvarovite-tremolite skarn (No. 4876), analyst: E. Condliffe. 
Table 2. Microprobe analyses of chromite in dolomite from Raivionmäki, Outokumpu.

\begin{tabular}{|c|c|c|c|c|c|c|c|c|c|c|c|c|}
\hline & $1 \mathrm{r}$ & $2 c$ & $3 r$ & $4 \mathrm{r}$ & $5 r$ & $6 c$ & $7 \mathrm{c}$ & $8 c$ & $9 \mathrm{r}$ & $10 \mathrm{c}$ & $11 \mathrm{r}$ & $12 r$ \\
\hline $\mathrm{SiO}_{2}$ & 0.24 & 0.25 & 0.19 & 0.21 & 0.16 & 0.06 & 0.31 & 0.16 & 0.17 & 0.06 & 0.16 & 0.18 \\
\hline $\mathrm{TiO}_{2}$ & 0.19 & 0.15 & 0.36 & 0.14 & 0.29 & 0.11 & 0.12 & 0.05 & 0.13 & 0.02 & 0.18 & 0.16 \\
\hline $\mathrm{Al}_{2} \mathrm{O}_{3}$ & 13.80 & 24.87 & 14.54 & 15.82 & 12.37 & 20.32 & 19.53 & 21.71 & 8.29 & 20.47 & 13.44 & 11.57 \\
\hline $\mathrm{Cr}_{2} \mathrm{O}_{3}$ & 41.58 & 38.47 & 39.74 & 41.31 & 43.14 & 40.74 & 38.87 & 37.98 & 51.66 & 37.66 & 43.03 & 45.74 \\
\hline $\mathrm{V}_{2} \mathrm{O}_{3}$ & 0.18 & 0.10 & 0.16 & 0.15 & 0.15 & 0.21 & 0.20 & 0.13 & 0.11 & 0.25 & 0.14 & 0.06 \\
\hline $\mathrm{FeO}$ & 41.20 & 32.08 & 41.93 & 39.26 & 40.51 & 35.47 & 37.59 & 36.00 & 36.98 & 37.49 & 40.32 & 39.30 \\
\hline $\mathrm{MnO}$ & 0.28 & 0.05 & 0.00 & 0.21 & 0.12 & 0.10 & 0.17 & 0.27 & 0.09 & 0.28 & 0.26 & 0.23 \\
\hline $\mathrm{MgO}$ & 0.80 & 2.85 & 0.82 & 1.16 & 1.21 & 2.07 & 2.42 & 2.26 & 0.67 & 1.88 & 0.79 & 0.84 \\
\hline $\mathrm{ZnO}$ & 0.64 & 1.13 & 0.67 & 1.01 & 0.60 & 1.18 & 0.88 & 0.95 & 0.68 & 0.68 & 0.63 & 0.75 \\
\hline $\mathrm{NiO}$ & 0.00 & 0.00 & 0.04 & 0.05 & 0.00 & 0.14 & 0.01 & 0.01 & 0.00 & 0.25 & 0.00 & 0.00 \\
\hline $\mathrm{CaO}$ & 0.37 & 0.07 & 0.33 & 0.10 & 0.58 & 0.05 & 0.03 & 0.00 & 0.10 & 0.07 & 0.03 & 0.39 \\
\hline Total & 99.28 & 100.02 & 98.78 & 100.42 & 99.13 & 100.40 & 100.13 & 99.52 & 98.88 & 99.12 & 98.98 & 99.23 \\
\hline
\end{tabular}

$\mathrm{r}-$ denotes rim of a grain, $\mathrm{c}-$ core or core region of a grain, analyst: E. Condliffe.

During the course of this study the chromite in the ankeritic dolomite from Raivionmäki has been analyzed by microprobe. The results (Table 2 and Fig. 1) show that the chemical composition of this chromite, apart from being moderately zinc-bearing, is totally different from the anomalous, zincian chromites of the skarns and it may indeed represent the composition of the primary chromite, as envisaged by Eskola. The mineral is rather high in aluminium and iron and low in magnesium, and resembles certain chromites from stratiform deposits associated with ultrabasic rocks. It also shows the common alter-

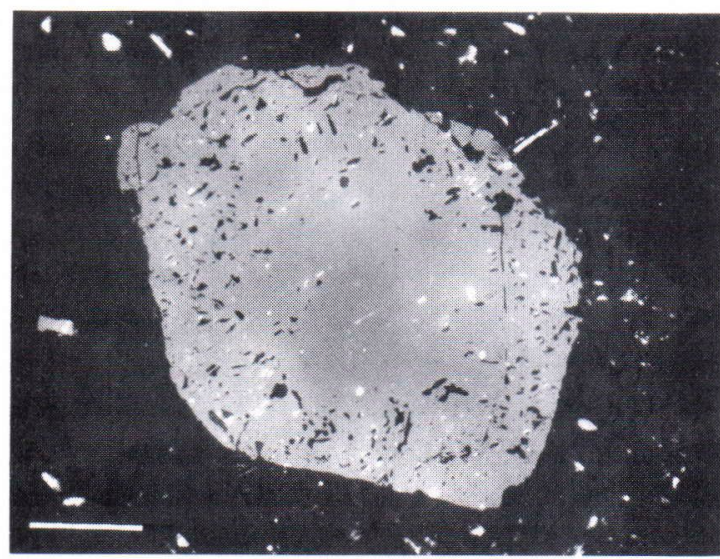

Fig. 1. Chrome spinel from the ankeritic dolomite at Raivionmäki. The inclusion free core is $\mathrm{Al}$ rich; the outer, inclusion bearing zone is enriched in $\mathrm{Fe}$ and Cr. Sp. 4885. B.E.I. Scale bar $=200 \mu \mathrm{m}$. ation phenomena as observed in chromites from other deposits, e.g., a marked enrichment trend of iron and to some extent of chromium from core to rim, with corresponding depletion of aluminium and magnesium.

Tables 3 and 4 show the microprobe analyses of a range of characteristic zincian chromites from various skarn mineral associations. As regards their occurrence and composition they may be divided into two major groups:

1. Zincian chromites found in veinlets, stringers, accumulations or as discrete grains in chromiferous skarns.

2. Zincian chromites almost always observed as inclusions or relicts within discrete uvarovite crystals.

The zincian chromites of the first group are characterized by high chromium and manganese contents, usually over 60 percent $\mathrm{Cr}_{2} \mathrm{O}_{3}$ and over 4 percent $\mathrm{MnO}$, whereas zinc is from 7-8 percent $\mathrm{ZnO}$. Iron and aluminium are variable, the latter in particular, shows higher values in the altered chromites, and magnesium is rather low.

The zincian chromites of the second group consist of two distinct varieties - one is associated with the large uvarovite crystals in the quartzbanded diopside skarn - the other is enclosed in smaller crystals of uvarovite, in the pyrrhotite-chalcopyrite-diopside skarn. The first variety has higher aluminium and, in particular, 
Table 3. Microprobe analyses of zincian chromites associated with uvarovites from Outokumpu.

\begin{tabular}{|c|c|c|c|c|c|c|c|c|c|c|c|c|}
\hline & 1 & 2 & 3 & $4 \mathrm{~h}$ & $5 \mathrm{~h}$ & $6 \mathrm{~s}$ & $7 \mathrm{~s}$ & $8 \mathrm{~h}$ & 9 & $10 \mathrm{~s}$ & $11 \mathrm{~h}$ & $12 \mathrm{~s}$ \\
\hline $\mathrm{SiO}_{2}$ & 1.44 & 0.39 & 0.44 & 0.27 & 0.27 & 0.41 & 0.90 & 0.37 & 0.28 & 0.38 & 0.40 & 0.32 \\
\hline $\mathrm{TiO}_{2}$ & 0.01 & 0.00 & 0.00 & 0.00 & 0.00 & 0.05 & 0.04 & 0.02 & 0.07 & 0.00 & 0.04 & 0.00 \\
\hline $\mathrm{Al}_{2} \mathrm{O}_{3}$ & 10.83 & 10.29 & 11.83 & 6.10 & 6.14 & 5.59 & 5.49 & 6.54 & 8.37 & 9.39 & 3.05 & 10.41 \\
\hline $\mathrm{Cr}_{2} \mathrm{O}_{3}$ & 58.05 & 58.72 & 57.60 & 61.66 & 61.68 & 62.48 & 60.14 & 60.02 & 57.10 & 56.45 & 64.92 & 56.38 \\
\hline $\mathrm{V}_{2} \mathrm{O}_{3}$ & 0.24 & 0.34 & 0.20 & 0.13 & 0.13 & 0.00 & 0.00 & 0.10 & 0.03 & 0.11 & 0.00 & 0.06 \\
\hline $\mathrm{FeO}$ & 9.96 & 10.42 & 9.95 & 17.71 & 17.71 & 17.62 & 18.32 & 18.21 & 20.03 & 19.15 & 19.51 & 19.33 \\
\hline $\mathrm{MnO}$ & 1.54 & 1.77 & 1.51 & 4.62 & 4.62 & 4.58 & 4.81 & 4.83 & 4.21 & 3.51 & 4.56 & 4.17 \\
\hline $\mathrm{MgO}$ & 8.19 & 7.73 & 8.19 & 1.04 & 1.35 & 1.77 & 1.37 & 1.22 & 0.71 & 1.23 & 0.88 & 1.82 \\
\hline $\mathrm{ZnO}$ & 10.18 & 10.15 & 10.29 & 8.25 & 8.25 & 8.06 & 7.93 & 8.42 & 7.81 & 8.60 & 6.66 & 8.05 \\
\hline $\mathrm{NiO}$ & 0.00 & 0.00 & 0.02 & 0.00 & 0.00 & 0.00 & 0.10 & 0.00 & 0.00 & 0.00 & 0.15 & 0.03 \\
\hline $\mathrm{CaO}$ & 0.13 & 0.18 & 0.22 & 0.30 & 0.31 & 0.16 & 0.26 & 0.34 & 0.81 & 0.35 & 0.27 & 0.12 \\
\hline Total & 100.53 & 99.99 & 100.25 & 100.08 & 100.46 & 100.72 & 99.36 & 100.07 & 99.42 & 99.17 & 100.44 & 100.69 \\
\hline
\end{tabular}

Analyses 1-3, zincian chromite inclusions in large uvarovite crystal from quartz-banded diopside skarn, sp. No. 4724. Analyses $4-8$, zincian chromite associated with pyrrhotite-chalcopyrite, diopside and quartz, sp. No. 4886, h - denotes homogenous chromite, $\mathrm{s}$ - porous chromite.

Analyses 9-12, zincian chromite in fine-grained uvarovite skarn, sp. No. 4877, analyst: E. Condliffe.

Table 4. Microprobe analyses of zincian chromite enclosed in uvarovite crystals from Outokumpu.

\begin{tabular}{|c|c|c|c|c|c|c|c|c|c|c|c|c|c|c|c|c|}
\hline & 1 & 2 & 3 & 4 & 5 & 6 & 7 & 8 & 9 & $10 \mathrm{~h}$ & $11 \mathrm{~s}$ & $12 \mathrm{~s}$ & $13 \mathrm{~h}$ & $14 \mathrm{~h}$ & $15 \mathrm{~s}$ & \\
\hline $\mathrm{iO}_{2}$ & 1.00 & 0.23 & 0.22 & 0.30 & 0.63 & 0.28 & 1.50 & 0.52 & 0.53 & 0.30 & 0.46 & 0.53 & 0.39 & 0.26 & 0.43 & \\
\hline $\mathrm{TiO}_{2}$ & 0.00 & 0.00 & 0.00 & 0.00 & 0.02 & 0.03 & 0.04 & 0.04 & 0.03 & 0.01 & 0.00 & 0.02 & 0.03 & 0.04 & 0.00 & 0.0 \\
\hline $\mathrm{Al}_{2} \mathrm{O}_{3}$ & 7.09 & 6.25 & 6.28 & 5.32 & 4.87 & 4.36 & 5.66 & 5.49 & 5.46 & 1.98 & 7.24 & 7.55 & 2.56 & 1.44 & 5.81 & 2. \\
\hline $\mathrm{Cr}_{2} \mathrm{O}_{3}$ & 55.79 & 57.62 & 57.88 & 58.32 & 57.9 & 59.62 & 54.24 & 57.0 & 56.74 & 66.21 & 58.12 & 57.99 & 64.04 & 66.46 & 59.43 & \\
\hline $\mathrm{V}_{2} \mathrm{O}_{3}$ & 0.15 & 0.25 & 0.24 & 0.33 & 0.67 & 0.42 & 0.70 & 0.70 & 0.7 & 0.00 & 0.35 & 0.21 & 0.11 & 0.11 & 0.22 & 0.0 \\
\hline $\mathrm{FeO}$ & 18.28 & 18.58 & 18.70 & 18.21 & 21.79 & 22.19 & 21.47 & 23.45 & 23.30 & 15.76 & 14.63 & 14.44 & 15.71 & 15.74 & 15.65 & 16. \\
\hline $\mathrm{AnO}$ & 1.14 & & 1.01 & & & & & & & & & & 1.65 & & 1.44 & 1. \\
\hline $\mathrm{MgO}$ & 1.60 & 1.44 & 1.46 & 1.37 & 0.35 & 0.31 & 1.06 & & & 2.41 & 2.91 & 3.15 & 2.44 & 2.68 & 2.69 & 2. \\
\hline $\mathrm{ZnO}$ & 13.86 & 13.37 & 13.41 & 12.99 & 10.90 & 11.36 & 10.92 & & 9.5 & 11.76 & 13.98 & 13.57 & 12.05 & 11.62 & 13.37 & 12.4 \\
\hline $\mathrm{NiO}$ & 0.00 & 0.00 & 0.00 & 0.23 & 0.12 & 0.08 & 0.01 & & & 0.05 & 0.00 & 0.00 & 0.03 & 0.01 & 0.00 & 0. \\
\hline $\mathrm{CaO}$ & 0.32 & 0.29 & 0.27 & 0.38 & 0.20 & 0.09 & 0.50 & 0.13 & 0.15 & 0.28 & 0.13 & 0.78 & 0.51 & 0.48 & 0.47 & 0.6 \\
\hline
\end{tabular}

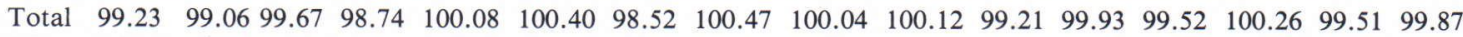

Analyses $1-9$, zincian chromite inclusions in uvarovite crystals from pyrrhotite-chalcopyrite ore, sp. No. 4878.

Analyses 10-16, zincian chromite inclusions in uvarovite crystals from pyrrhotite-chalcopyrite-diopside ore, sp. No. 4881, $\mathrm{h}$ - denotes homogenous chromite, s - porous chromite inclusions, analyst: E. Condliffe.

magnesium contents, whereas chromium and iron are much lower than in the first group. Zinc is distinctly higher, around 10 percent $\mathrm{ZnO}$, and manganese is low.

The second variety is characterized by the extremely high zinc content, which may be up to $14 \% \mathrm{ZnO}$. Aluminium, chromium and iron are rather variable, depending on the alteration state of the chromite. Magnesium is similar to the first group of chromites, but manganese is much lower. The vanadium content, although below one percent is distinct, and markedly higher, than in the zincian chromites of the first group.

While examining eskolaite by microprobe an unusual variety of a vanadium-bearing zincian chromite was noted. Eskolaite $\left(\mathrm{Cr}_{2} \mathrm{O}_{3}\right)$, was described as a new mineral by Kouvo and Vuorelainen in 1958. This interesting mineral occurring in tiny, black hexagonal prisms, rather like tourmaline in appearance, is found sparingly in a number of skarns at Outokumpu. Subsequently eskolaite was re-examined and an alteration pro- 


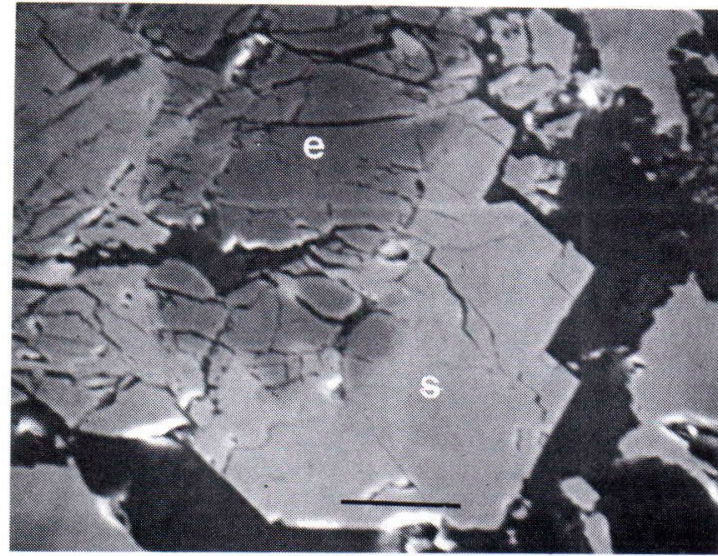

Fig. 2. Vanadian eskolaite (e), showing marginal replacement to chromite (s). Sp. 4875. B.E.I. Scale bar $=25 \mu \mathrm{m}$.

duct, a hydrated vanadium-bearing chromium oxide was noted, Vuorelainen et al. (1968).

During the present study, crystals of eskolaite occurring in a rich chalcopyrite-pyrrhotite ore were found to be marginally replaced by a zincian chromite (Fig. 2), previously not observed in this association. The composition of this particular zincian spinel (Table 5) is markedly different from the zincian chromites associated with the uvarovite skarns, in that the chromium and vanadium contents are much higher and aluminium is exceedingly low, iron and zinc are similar to the previous zincian chromites. A characteristic feature of eskolaite is its high vanadium content (Table 6), and consequently the present chromite has incorporated most of the available vanadium into its structure.

It is interesting to note, that Long et al. (1963) have recorded a manganese-iron-vanadium spinel associated with karelianite $\left(\mathrm{V}_{2} \mathrm{O}_{3}\right)$, the vanadian analogue of eskolaite, at Outokumpu.

\section{Chrome-garnets}

Among chromium-bearing garnets the emerald green uvarovite is the most outstanding. The first find of uvarovite from Outokumpu (Sysmä,

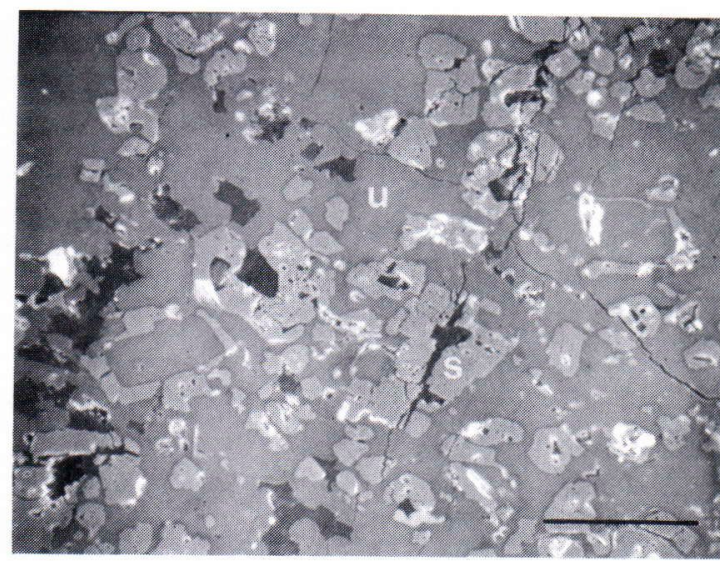

Fig. 3. Intergrowth of massive uvarovite (u) and porous chromite (s). This is an example of the group 3 garnet association (for explanation see text). Sp. 4886 B.E.I. Scale bar $=100 \mu \mathrm{m}$.

Kuusjärvi) as recorded by Borgström (1901) came from vugs in a quartzite closely associated with a serpentinite. The garnet was analyzed, and this first analysis, still shows the highest chromium content of any chemically analyzed uvarovite so far.

Although uvarovite garnets have been recorded from numerous localities in the literature, they are seldom found in large amounts, and in most cases the green garnets are, as regards their composition, chromian grossulars.

As indicated earlier, the uvarovite at Outokumpu may be found in a number of mineral associations, both in the various chromiferous skarns and also within the sulphide ore. Locally it may occur in the form of a fine-grained massive, uvarovite rock, where garnet is the dominant mineral (Fig. 3). The best development of garnet is seen in a quartz-banded, chromian diopside-sulphide skarn, where clusters of excellent dark green, uvarovite crystals, showing dodecahedral and trapezohedral forms, are found within the glassy quartz matrix, marginal to the diopside bands. Scattered single crystals of uvarovite may be seen in the centre of the narrower quartz bands or at the contact between the quartz- and the diopside bands. The size of the crystals is usually up to $10 \mathrm{~mm}$ in diameter, but 
Table 5. Microprobe analyses of zincian chromite replacing eskolaite.

\begin{tabular}{lrrrrrrr}
\hline & 1 & 2 & 3 & 4 & 5 & 6 \\
\hline $\mathrm{SiO}_{2}$ & 0.12 & 0.10 & 0.30 & 0.41 & 0.41 & 0.45 & 0.36 \\
$\mathrm{TiO}_{2}$ & 0.04 & 0.00 & 0.02 & 0.00 & 0.12 & 0.00 & 0.18 \\
$\mathrm{Al}_{2} \mathrm{O}_{3}$ & 0.25 & 0.13 & 0.06 & 0.53 & 0.65 & 0.39 & 0.71 \\
$\mathrm{Cr}_{2} \mathrm{O}_{3}$ & 68.65 & 64.49 & 67.89 & 63.81 & 64.75 & 64.53 & 63.75 \\
$\mathrm{~V}_{2} \mathrm{O}_{3}$ & 0.85 & 3.72 & 1.02 & 2.74 & 2.24 & 2.15 & 2.43 \\
$\mathrm{FeO}$ & 17.32 & 20.67 & 18.65 & 22.23 & 22.35 & 23.75 & 23.38 \\
$\mathrm{MnO}$ & 1.54 & 1.79 & 1.75 & 2.28 & 2.18 & 2.76 & 2.41 \\
$\mathrm{MgO}$ & 4.03 & 1.49 & 3.04 & 0.00 & 0.00 & 0.00 & 0.22 \\
$\mathrm{ZnO}$ & 7.60 & 7.77 & 7.24 & 7.89 & 8.02 & 6.36 & 6.75 \\
$\mathrm{NiO}$ & 0.00 & 0.24 & 0.00 & 0.00 & 0.06 & 0.03 & 0.00 \\
$\mathrm{CaO}$ & 0.09 & 0.00 & 0.00 & 0.09 & 0.00 & 0.09 & 0.00 \\
\hline & 100.49 & 100.40 & 99.97 & 99.98 & 100.78 & 100.51 & 100.19 \\
\hline
\end{tabular}

analyst: E. Condliffe.

Table 6. Microprobe analyses of eskolaite.

\begin{tabular}{|c|c|c|c|c|c|c|c|c|}
\hline & $1 \mathrm{r}$ & $2 c$ & $3 c$ & $4 \mathrm{r}$ & $5 r$ & $6 r$ & $7 c$ & $8 c$ \\
\hline $\mathrm{Cr}_{2} \mathrm{O}_{3}$ & 92.98 & 97.97 & 97.18 & 95.35 & 92.60 & 95.26 & 96.85 & 96.85 \\
\hline $\mathrm{V}_{2} \mathrm{O}_{3}$ & 5.08 & 2.05 & 2.59 & 3.09 & 7.06 & 2.51 & 3.36 & 2.24 \\
\hline $\mathrm{Al}_{2} \mathrm{O}_{3}$ & 0.61 & 0.03 & 0.31 & 0.38 & 0.22 & 1.47 & 0.20 & 0.12 \\
\hline $\mathrm{Fe}_{2} \mathrm{O}_{3}$ & 0.61 & 0.09 & 0.11 & 0.69 & 0.74 & 0.23 & 0.21 & 0.15 \\
\hline \multirow[t]{3}{*}{$\mathrm{MnO}$} & 0.07 & 0.00 & 0.11 & 0.16 & 0.00 & 0.12 & 0.03 & 0.04 \\
\hline & 99.35 & 100.14 & 100.30 & 100.67 & 100.62 & 99.59 & 100.65 & 99.40 \\
\hline & $9 \mathrm{r}$ & $10 \mathrm{r}$ & $11 \mathrm{r}$ & $12 \mathrm{r}$ & $13 r$ & $14 \mathrm{r}$ & $15 \mathrm{c}$ & $16 \mathrm{c}$ \\
\hline $\mathrm{Cr}_{2} \mathrm{O}_{3}$ & 96.70 & 97.43 & 96.09 & 96.46 & 96.19 & 96.75 & 95.03 & 94.50 \\
\hline $\mathrm{V}_{2} \mathrm{O}_{3}$ & 2.04 & 2.09 & 2.88 & 3.20 & 3.18 & 2.86 & 3.06 & 2.95 \\
\hline $\mathrm{Al}_{2} \mathrm{O}_{3}$ & 0.10 & 0.00 & 0.35 & 0.34 & 0.26 & 0.09 & 0.75 & 1.47 \\
\hline $\mathrm{Fe}_{2} \mathrm{O}_{3}$ & 0.86 & 0.31 & 0.34 & 0.55 & 0.40 & 0.39 & 0.20 & 0.19 \\
\hline \multirow[t]{3}{*}{$\mathrm{MnO}$} & 0.00 & 0.00 & 0.05 & 0.00 & 0.00 & 0.00 & 0.10 & 0.13 \\
\hline & 99.70 & 99.83 & 99.71 & 100.55 & 100.03 & 100.09 & 99.14 & 99.24 \\
\hline & $17 \mathrm{c}$ & $18 \mathrm{r}$ & $19 c$ & $20 c$ & & & & \\
\hline $\mathrm{Cr}_{2} \mathrm{O}_{3}$ & 95.76 & 93.19 & 95.97 & 97.07 & & & & \\
\hline $\mathrm{V}_{2} \mathrm{O}_{3}$ & 3.14 & 6.16 & 2.83 & 2.78 & & & & \\
\hline $\mathrm{Al}_{2} \mathrm{O}_{3}$ & 1.00 & 0.04 & 0.00 & 0.04 & & & & \\
\hline $\mathrm{Fe}_{2} \mathrm{O}_{3}$ & 0.22 & 0.60 & 0.30 & 0.23 & & & & \\
\hline \multirow[t]{2}{*}{$\mathrm{MnO}$} & 0.00 & 0.00 & 0.10 & 0.00 & & & & \\
\hline & 100.12 & 99.99 & 99.21 & 100.12 & & & & \\
\hline
\end{tabular}

$\mathrm{r}$ - denotes rim of grain, $\mathrm{c}-$ core or core region of a grain, analyst: E. Condliffe.

occasionally, garnets up to $45 \mathrm{~mm}$ across have been noted (Fig. 4).

A closer examination of the uvarovite garnets under the microscope frequently reveals a distinct zoning, consisting of a core and a rim. The core section may contain variable amounts of tiny in- clusions, mainly of zincian chromite, but also diopside, calcite, albite, micas, chlorite and various sulphides. The rim section, on the other hand, seems to be free of inclusions and consists of fresh uvarovite.

The presence of chromite is significant, since 


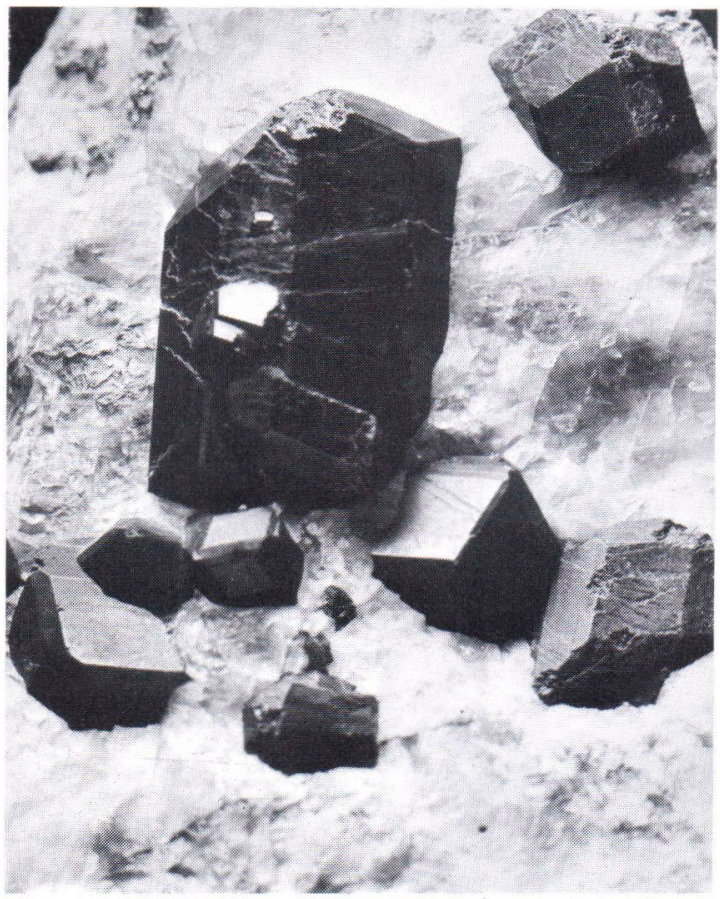

Fig. 4. A group of large uvarovite crystals embedded in quartz. Length of the largest crystal $4.5 \mathrm{~cm}$. Outokumpu mine, Outokumpu, Finland. Specimen No. C 558, Mineralogical Museum, University of Helsinki.

it appears that much of the uvarovite has been formed by replacement of original chromite, and grains of chromite, in various stages of alteration are seen abundantly in the core zone (Figs. 5, 6 and 7). Frequently the outlines of the original chromite crystals are indicated by small fragments of chromite grains, typically fringed by perforated rims. At times the entire core section may consist of a single, fringed chromite crystal, with interstitial uvarovite, surrounded by a narrow rim of clear uvarovite.

In Table 7 the known, wet chemical analyses of uvarovites from chromiferous skarn associations in the Outokumpu region are presented. A large number of uvarovites have been examined by microprobe, in order to observe any compositional zonation trends or elemental variation of individual grains or crystals.

Microprobe analyses are presented in Tables 8. to 11 . Taken as a whole the garnets all show
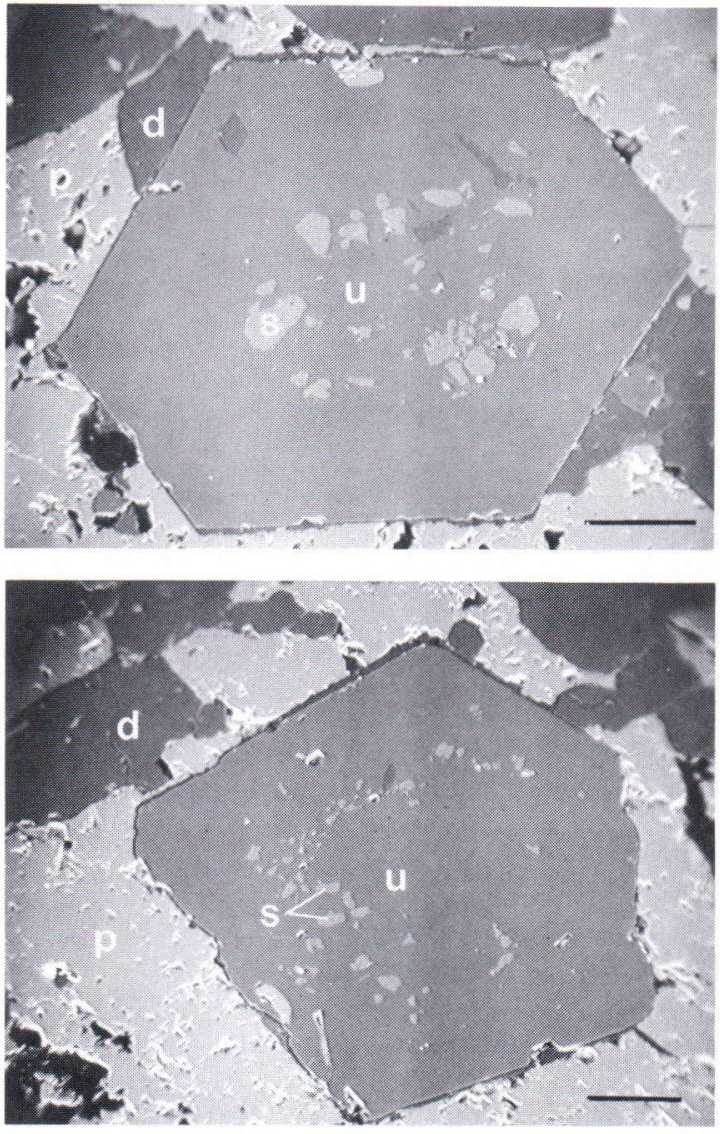

Figs. 5 and 6. Examples of group 2 uvarovites. Discrete euhedral garnets $(u)$, set in a matrix of pyrrhotite $(p)$ and chromian diopside (d). Note the trails of relict porous chromite (s). Sp. 4881 B.E.I. Scale bar $=200 \mu \mathrm{m}$.

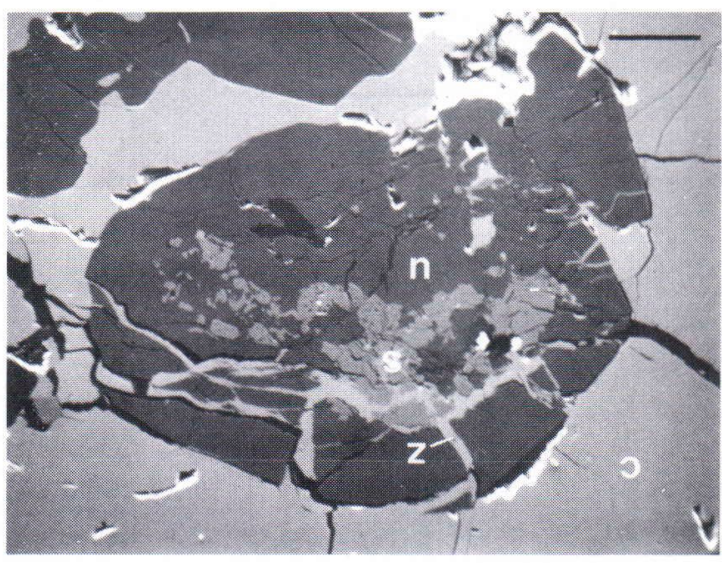

Fig. 7. Uvarovite grain (u) enclosed in chalcopyrite (c). The uvarovite contains inclusions of porous chromite (s) and is veined by zinc blend (z). Sp. 4878. B.E.I. Scale bar $=200 \mu \mathrm{m}$. 
Table 7. Chemical composition and physical properties of uvarovites from northern Karelia.

\begin{tabular}{|c|c|c|c|c|c|c|c|c|}
\hline & 1 & 2 & 3 & 4 & 5 & 6 & 7 & 8 \\
\hline $\mathrm{SiO}_{2}$ & 38.68 & 38.40 & 37.21 & 37.08 & 36.93 & 37.31 & 35.88 & 36.79 \\
\hline $\mathrm{TiO}_{2}$ & - & - & 0.24 & 0.16 & 0.08 & - & - & - \\
\hline $\mathrm{Al}_{2} \mathrm{O}_{3}$ & 12.00 & 10.77 & 9.56 & 8.70 & 5.54 & 5.34 & 1.13 & 1.93 \\
\hline $\mathrm{Cr}_{2} \mathrm{O}_{3}$ & 12.25 & 14.97 & 15.75 & 18.57 & 22.15 & 22.60 & 27.04 & 27.54 \\
\hline $\mathrm{Fe}_{2} \mathrm{O}_{3}$ & 2.47 & 1.89 & 2.16 & 0.87 & 1.07 & 0.30 & 2.46 & 0.41 \\
\hline $\mathrm{FeO}$ & - & - & 0.88 & nil & 0.46 & - & - & - \\
\hline $\mathrm{MnO}$ & - & - & 0.45 & 0.33 & 0.26 & 0.15 & 0.03 & - \\
\hline $\mathrm{MgO}$ & 0.20 & 0.48 & 0.54 & 0.61 & 0.71 & 0.25 & 0.04 & 0.50 \\
\hline $\mathrm{CaO}$ & 34.04 & 33.08 & 32.98 & 33.68 & 32.24 & 34.25 & 33.31 & 32.74 \\
\hline $\mathrm{Na}_{2} \mathrm{O}$ & - & - & 0.09 & 0.15 & 0.10 & - & - & - \\
\hline $\mathrm{K}_{2} \mathrm{O}$ & - & - & 0.01 & 0.01 & 0.01 & - & - & - \\
\hline $\mathrm{H}_{2} \mathrm{O}+$ & 0.20 & 0.40 & 0.10 & 0.05 & 0.33 & 0.10 & 0.18 & - \\
\hline \multirow[t]{2}{*}{$\mathrm{H}_{2} \mathrm{O}-$} & - & - & 0.04 & 0.08 & 0.03 & - & - & - \\
\hline & 99.84 & 99.99 & 100.01 & 100.29 & 99.91 & 100.30 & 100.07 & 99.91 \\
\hline $\mathrm{D}$ & 3.676 & 3.712 & 3.770 & 3.793 & 3.815 & 3.809 & - & 3.772 \\
\hline a & $11.881 \AA$ & $11.892 \AA$ & $11.904 \AA$ & $11.932 \AA$ & $11.951 \AA$ & $11.922 \AA$ & - & $11.950 \AA$ \\
\hline $\mathrm{n}$ & 1.796 & $1.798-1.804$ & $1.803-1.808$ & $1.808-1.814$ & $1.819-1.824$ & $1.821-1.829$ & - & 1.8554 \\
\hline
\end{tabular}

1. Grossular-uvarovite in pyrrhotite-quartzite, Luikonlahti, analyst: O. von Knorring.

2. Uvarovite in pyrrhotite-diopside ore, Luikonlahti, analyst: O. von Knorring.

3. Uvarovite in pyrrhotite-chalcopyrite-diopside ore, Outokumpu, analyst: Y. L. Tong.

4. Uvarovite in quartz, Outokumpu, analyst: Y. L. Tong.

5. Uvarovite in pyrrhotite-diopside-tremolite-chromite skarn Outokumpu, analyst: Y. L. Tong.

6. Uvarovite in diopside-tremolite skarn, Outokumpu, analyst: O. von Knorring.

7. Uvarovite in tremolite-chrome-epidote-pyrrhotite vein, Outokumpu, analyst: L. Lokka.

8. Uvarovite in vugs in quartzite, Outokumpu, analyst: L. H. Borgström.

Table 8. Microprobe analysis of a single crystal of uvarovite enclosed in quartz, Outokumpu.

\begin{tabular}{|c|c|c|c|c|c|c|c|c|c|c|c|c|}
\hline & $1 \mathrm{r}$ & 2 & 3 & 4 & 5 & 6 & $7 \mathrm{c}$ & $8 c$ & 9 & 10 & 11 & $12 \mathrm{r}$ \\
\hline $\mathrm{SiO}_{2}$ & 37.10 & 37.47 & 37.15 & 37.62 & 37.62 & 37.41 & 37.91 & 36.99 & 37.31 & 37.60 & 37.05 & 37.52 \\
\hline $\mathrm{TiO}_{2}$ & 0.26 & 0.18 & 0.07 & 0.09 & 0.06 & 0.05 & 0.11 & 0.12 & 0.05 & 0.03 & 0.00 & 0.17 \\
\hline $\mathrm{Al}_{2} \mathrm{O}_{3}$ & 7.73 & 7.86 & 8.23 & 8.36 & 8.61 & 8.18 & 8.73 & 8.23 & 8.45 & 8.65 & 8.24 & 8.18 \\
\hline $\mathrm{Cr}_{2} \mathrm{O}_{3}$ & 19.44 & 18.84 & 18.93 & 18.62 & 18.52 & 18.68 & 18.49 & 18.18 & 18.62 & 18.48 & 18.59 & 18.45 \\
\hline $\mathrm{V}_{2} \mathrm{O}_{3}$ & 0.23 & 0.17 & 0.17 & 0.19 & 0.19 & 0.08 & 0.13 & 0.23 & 0.21 & 0.25 & 0.15 & 0.09 \\
\hline $\mathrm{Fe}_{2} \mathrm{O}_{3}$ & 0.44 & 0.58 & 0.63 & 0.57 & 0.52 & 0.70 & 0.60 & 0.64 & 0.60 & 0.71 & 0.66 & 0.71 \\
\hline $\mathrm{MnO}$ & 0.61 & 0.64 & 0.63 & 0.81 & 0.57 & 0.79 & 0.82 & 0.67 & 0.63 & 0.61 & 0.65 & 0.68 \\
\hline $\mathrm{MgO}$ & 0.59 & 0.45 & 0.61 & 0.59 & 0.35 & 0.41 & 0.50 & 0.60 & 0.63 & 0.91 & 0.71 & 0.59 \\
\hline $\mathrm{CaO}$ & 33.41 & 33.55 & 33.31 & 33.33 & 33.50 & 33.40 & 33.32 & 33.24 & 33.31 & 33.08 & 33.37 & 33.12 \\
\hline Total & 99.81 & 99.74 & 99.68 & 100.18 & 99.94 & 99.70 & 100.61 & 98.90 & 99.81 & 100.32 & 99.42 & 99.51 \\
\hline
\end{tabular}

Garnet end-member proportions:

\begin{tabular}{|c|c|c|c|c|c|c|c|c|c|c|c|c|}
\hline $\mathrm{Gm}$ & 0.8 & 0.6 & 0.6 & 0.6 & 0.6 & 0.3 & 0.5 & 0.8 & 0.7 & 0.8 & 0.5 & 0.3 \\
\hline Uv & 63.4 & 62.1 & 61.1 & 60.4 & 59.7 & 61.0 & 59.3 & 60.0 & 60.1 & 59.1 & 60.6 & 60.6 \\
\hline An & 1.4 & 1.8 & 1.9 & 1.8 & 1.6 & 2.2 & 1.8 & 2.0 & 1.9 & 2.2 & 2.1 & 2.2 \\
\hline Py & 2.4 & 1.9 & 2.5 & 2.4 & 1.4 & 1.7 & 2.0 & 2.5 & 2.5 & 3.7 & 2.9 & 2.4 \\
\hline $\mathrm{Sp}$ & 1.4 & 1.5 & 1.5 & 1.9 & 1.3 & 1.9 & 1.9 & 1.6 & 1.4 & 1.4 & 1.5 & 1.6 \\
\hline Gr & 30.7 & 32.1 & 32.5 & 32.9 & 35.3 & 33.1 & 34.5 & 33.1 & 33.4 & 32.8 & 32.4 & 32.8 \\
\hline
\end{tabular}

Traverse across a large uvarovite crystal from rim to rim, at $0.5 \mathrm{~mm}$ intervals Sp. No. 4884 , analyst: E. Condliffe. 
Table 9. Microprobe analyses of uvarovite crystals enclosed in pyrrhotite-chalcopyrite ore, Outokumpu.

\begin{tabular}{lrrrrrrrrrrrrrr}
\hline & $1 \mathrm{r}$ & \multicolumn{1}{c}{$2 \mathrm{c}$} & \multicolumn{1}{c}{$3 \mathrm{c}$} & \multicolumn{1}{c}{$4 \mathrm{r}$} & \multicolumn{1}{c}{$5 \mathrm{r}$} & \multicolumn{1}{c}{$6 \mathrm{r}$} & $7 \mathrm{r}$ & $8 \mathrm{c}$ & $9 \mathrm{c}$ & $10 \mathrm{r}$ & $11 \mathrm{r}$ & $12 \mathrm{r}$ & $13 \mathrm{c}$ & $14 \mathrm{c}$ \\
\hline $\mathrm{SiO}_{2}$ & 37.44 & 37.68 & 37.51 & 37.90 & 37.50 & 37.01 & 37.08 & 37.55 & 37.27 & 36.88 & 37.17 & 37.65 & 37.10 & 37.42 \\
$\mathrm{TiO}_{2}$ & 0.07 & 0.44 & 0.63 & 0.11 & 0.17 & 0.21 & 0.05 & 0.25 & 0.44 & 0.27 & 0.09 & 0.16 & 0.35 & 0.16 \\
$\mathrm{Al}_{2} \mathrm{O}_{3}$ & 9.26 & 10.04 & 10.16 & 9.78 & 9.85 & 8.75 & 5.53 & 9.78 & 9.62 & 7.76 & 6.86 & 9.00 & 9.62 & 9.63 \\
$\mathrm{Cr}_{2} \mathrm{O}_{3}$ & 15.91 & 15.26 & 15.36 & 16.32 & 15.74 & 16.54 & 22.15 & 16.09 & 16.12 & 17.50 & 18.90 & 16.17 & 15.97 & 16.11 \\
$\mathrm{~V}_{2} \mathrm{O}_{3}$ & 0.45 & 0.31 & 0.32 & 0.55 & 0.47 & 0.53 & 0.49 & 0.40 & 0.46 & 0.64 & 0.54 & 0.53 & 0.42 & 0.47 \\
$\mathrm{Fe}_{2} \mathrm{O}_{3}$ & 2.70 & 2.01 & 1.75 & 2.17 & 2.41 & 3.13 & 1.32 & 1.38 & 1.54 & 3.04 & 3.13 & 2.54 & 1.49 & 1.62 \\
$\mathrm{MnO}$ & 0.84 & 0.96 & 0.87 & 0.88 & 0.95 & 0.89 & 0.13 & 0.79 & 1.04 & 0.90 & 0.90 & 1.02 & 0.75 & 0.86 \\
$\mathrm{MgO}$ & 0.25 & 0.76 & 0.63 & 0.48 & 0.48 & 0.73 & 0.62 & 0.71 & 0.25 & 0.27 & 0.14 & 0.57 & 0.48 & 0.60 \\
$\mathrm{CaO}$ & 32.72 & 32.79 & 32.56 & 32.66 & 32.36 & 32.60 & 32.92 & 33.16 & 32.77 & 32.38 & 32.40 & 32.73 & 33.03 & 32.83 \\
\hline Total & 99.64 & 100.25 & 99.79 & 100.85 & 99.93 & 100.39 & 100.29 & 100.11 & 99.51 & 99.64 & 100.13 & 100.37 & 99.21 & 99.69 \\
\hline
\end{tabular}

Garnet end-member proportions:

\begin{tabular}{lrrrrrrrrrrrrrr} 
Gm & 1.5 & 1.0 & 1.1 & 1.8 & 1.6 & 1.7 & 1.7 & 1.3 & 1.6 & 2.2 & 1.9 & 1.8 & 1.4 & 1.5 \\
$\mathrm{Uv}$ & 52.2 & 48.8 & 49.8 & 53.1 & 51.5 & 53.3 & 72.3 & 51.5 & 52.6 & 57.9 & 62.8 & 52.1 & 51.5 & 51.9 \\
$\mathrm{An}$ & 8.4 & 6.1 & 5.4 & 6.7 & 7.5 & 9.6 & 4.1 & 4.2 & 4.8 & 9.6 & 9.9 & 7.8 & 4.6 & 5.0 \\
$\mathrm{Py}$ & 1.0 & 3.1 & 2.6 & 2.0 & 2.0 & 2.9 & 2.6 & 2.9 & 1.0 & 1.1 & 0.6 & 2.3 & 1.9 & 2.4 \\
$\mathrm{Sp}$ & 2.0 & 2.2 & 2.0 & 2.0 & 2.2 & 2.0 & 0.3 & 1.8 & 2.4 & 2.1 & 2.1 & 2.4 & 1.7 & 2.0 \\
$\mathrm{Gr}$ & 34.9 & 38.8 & 39.1 & 34.3 & 35.1 & 30.3 & 19.1 & 38.3 & 37.7 & 27.1 & 22.7 & 33.7 & 38.9 & 37.2 \\
\hline
\end{tabular}

Microprobe analyses of small uvarovite garnets from $2-5 \mathrm{~mm}$ across associated in the pyrrhotite-chalcopyrite ore sp. No. 4881, analyst: E. Condliffe.

$\mathrm{c}-$ denotes the core, $\mathrm{r}-$ the rim of the garnets.

Table 10. Microprobe analyses of uvarovites, Outokumpu.

\begin{tabular}{|c|c|c|c|c|c|c|c|c|c|c|c|c|}
\hline & 1 & 2 & 3 & 4 & 5 & 6 & 7 & 8 & 9 & 10 & 11 & 12 \\
\hline $\mathrm{SiO}_{2}$ & 37.00 & 36.64 & 36.58 & 37.21 & 36.98 & 36.87 & 36.94 & 36.97 & 37.19 & 37.66 & 36.81 & 37.00 \\
\hline $\mathrm{TiO}_{2}$ & 0.07 & 0.08 & 0.10 & 0.42 & 0.35 & 0.08 & 0.24 & 0.12 & 0.16 & 0.10 & 0.10 & 0.22 \\
\hline $\mathrm{Al}_{2} \mathrm{O}_{3}$ & 5.93 & 5.11 & 4.65 & 8.23 & 7.94 & 6.80 & 8.74 & 6.58 & 7.55 & 7.05 & 4.46 & 7.52 \\
\hline $\mathrm{Cr}_{2} \mathrm{O}_{3}$ & 21.60 & 22.76 & 23.83 & 18.75 & 18.93 & 20.96 & 18.24 & 20.99 & 19.96 & 20.40 & 23.69 & 20.27 \\
\hline $\mathrm{V}_{2} \mathrm{O}_{3}$ & 0.55 & 0.57 & 0.12 & 0.20 & 0.49 & 0.39 & 0.26 & 0.16 & 0.27 & 0.26 & 0.62 & 0.10 \\
\hline $\mathrm{Fe}_{2} \mathrm{O}_{3}$ & 0.49 & 0.32 & 0.37 & 0.48 & 0.51 & 0.80 & 0.40 & 0.59 & 0.52 & 0.56 & 0.63 & 0.30 \\
\hline $\mathrm{MnO}$ & 0.65 & 0.53 & 0.45 & 0.66 & 0.55 & 0.61 & 0.41 & 0.53 & 0.55 & 0.57 & 0.50 & 0.49 \\
\hline $\mathrm{MgO}$ & 0.41 & 0.39 & 0.31 & 0.40 & 0.40 & 0.15 & 0.47 & 0.36 & 0.35 & 0.41 & 0.28 & 0.62 \\
\hline $\mathrm{CaO}$ & 33.45 & 33.11 & 33.71 & 33.67 & 34.03 & 33.86 & 33.72 & 33.43 & 33.67 & 33.56 & 33.35 & 33.53 \\
\hline Total & 100.15 & 99.51 & 100.12 & 100.02 & 100.18 & 100.52 & 99.42 & 99.73 & 100.22 & 100.57 & 100.44 & 100.05 \\
\hline
\end{tabular}

Garnet end-member proportions:

\begin{tabular}{|c|c|c|c|c|c|c|c|c|c|c|c|c|}
\hline $\mathrm{Gm}$ & 1.9 & 1.9 & 0.4 & 0.7 & 1.6 & 1.3 & 0.9 & 0.5 & 0.9 & 0.8 & 2.1 & 0.3 \\
\hline Uv & 70.2 & 74.2 & 77.7 & 61.1 & 61.5 & 67.4 & 59.1 & 68.3 & 64.2 & 65.2 & 76.8 & 64.9 \\
\hline An & 1.5 & 1.0 & 1.2 & 1.5 & 1.6 & 2.4 & 1.2 & 1.8 & 1.6 & 1.7 & 1.9 & 0.9 \\
\hline Py & 1.7 & 1.6 & 1.3 & 1.6 & 1.6 & 0.6 & 1.9 & 1.5 & 1.4 & 1.7 & 1.1 & 2.5 \\
\hline $\mathrm{Sp}$ & 1.5 & 1.2 & 1.1 & 1.5 & 1.3 & 1.4 & 1.0 & 1.2 & 1.3 & 1.3 & 1.2 & 1.1 \\
\hline $\mathrm{Gr}$ & 23.2 & 20.0 & 18.4 & 33.5 & 32.4 & 26.9 & 36.0 & 26.6 & 30.6 & 29.2 & 16.9 & 30.2 \\
\hline
\end{tabular}

Analyses 1-6 of uvarovite, associated with a chromite band, grains at random, sp. No. 4876, analyst: E. Condliffe. Analyses 7-12 of uvarovite grains at random from a massive uvarovite rock sp. No. 4877, analyst: E. Condliffe.

high proportions of uvarovite (Uv) molecule; very rarely does the Uv content fall below $50 \%$. Except for the vanadium enriched uvarovite discussed below and the more andraditic garnets of sample 4881 (Tables 9 and 11), the only other dominant end-member is grossular ( $\mathrm{Gr}$ ); andradite (An), pyrope (Py), spessartine ( $\mathrm{Sp}$ ) and the rare $\mathrm{Ca}: \mathrm{V}$ end-member, goldmanite $(\mathrm{Gm})$, are 
Table 11. Microprobe analysis of vanadian uvarovite, Outokumpu.

\begin{tabular}{|c|c|c|c|c|c|c|c|}
\hline & $1 \mathrm{c}$ & $2 \mathrm{r}$ & $3 r$ & $4 c$ & $5 \mathrm{c}$ & $6 \mathrm{r}$ & $7 \mathrm{c}$ \\
\hline $\mathrm{SiO}_{2}$ & 36.25 & 36.62 & 36.36 & 36.50 & 35.97 & 36.54 & 36.69 \\
\hline $\mathrm{TiO}_{2}$ & 0.14 & 0.09 & 0.28 & 0.12 & 0.02 & 0.05 & 0.09 \\
\hline $\mathrm{Al}_{2} \mathrm{O}_{3}$ & 3.37 & 4.83 & 5.58 & 3.58 & 3.69 & 4.68 & 3.97 \\
\hline $\mathrm{Cr}_{2} \mathrm{O}_{3}$ & 23.14 & 21.53 & 20.11 & 24.44 & 24.64 & 22.94 & 24.52 \\
\hline $\mathrm{V}_{2} \mathrm{O}_{3}$ & 2.22 & 2.36 & 2.46 & 1.34 & 0.97 & 1.17 & 0.97 \\
\hline $\mathrm{Fe}_{2} \mathrm{O}_{3}$ & 0.38 & 0.51 & 0.41 & 0.28 & 0.54 & 0.46 & 0.46 \\
\hline $\mathrm{MnO}$ & 0.94 & 0.97 & 1.08 & 0.84 & 0.80 & 0.82 & 0.92 \\
\hline $\mathrm{MgO}$ & 0.47 & 0.59 & 0.65 & 0.17 & 0.52 & 0.29 & 0.55 \\
\hline $\mathrm{CaO}$ & 32.76 & 32.87 & 32.44 & 32.82 & 32.70 & 32.94 & 33.22 \\
\hline Total & 99.67 & 100.37 & 99.37 & 100.09 & 99.85 & 99.89 & 101.39 \\
\hline \multicolumn{8}{|c|}{ Garnet end-member proportions: } \\
\hline $\mathrm{Gm}$ & 7.6 & 7.9 & 8.3 & 4.5 & 3.3 & 3.9 & 3.3 \\
\hline Uv & 76.1 & 69.7 & 65.6 & 80.2 & 81.2 & 74.7 & 79.2 \\
\hline An & 1.2 & 1.6 & 1.3 & 0.9 & 1.7 & 1.4 & 1.4 \\
\hline Py & 1.9 & 2.4 & 2.7 & 0.7 & 2.2 & 1.2 & 2.2 \\
\hline $\mathrm{Sp}$ & 2.2 & 2.3 & 2.5 & 2.0 & 1.9 & 1.9 & 2.1 \\
\hline Gr & 11.0 & 16.2 & 19.7 & 11.7 & 9.8 & 16.9 & 11.7 \\
\hline
\end{tabular}

Analysis of vanadian uvarovite associated with a chromian clinozoisite in a tremolite skarn, sp. No. 4872 , analyst: E. Condliffe.

$\mathrm{c}-$ denotes the core, $\mathrm{r}-$ the rim of the garnets.

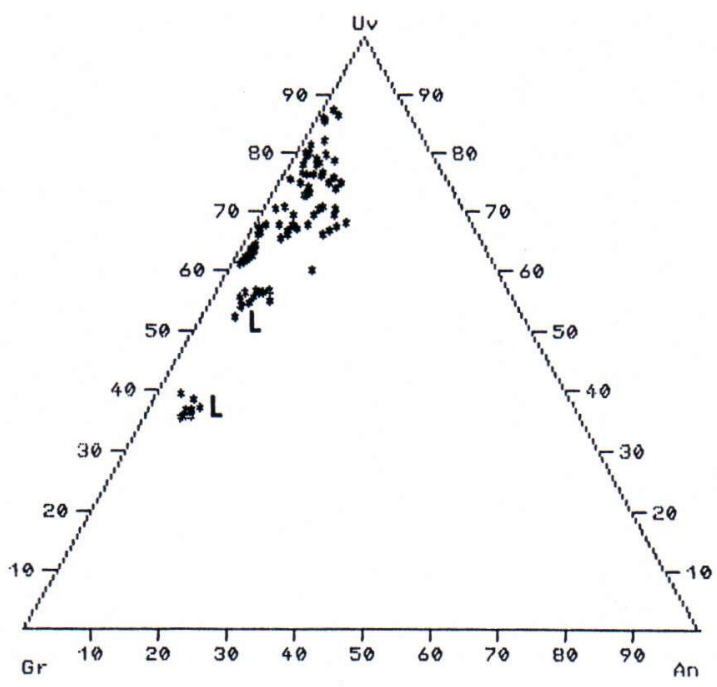

Fig. 8. Uvarovite: grossular: andradite garnet and member plot for 98 analyses of garnets from Outokumpu. The clusters of plots marked L are for garnets from Luikonlahti, a rock association closely resembling Outokumpu, present some $30 \mathrm{~km}$ to the N.W.

only present in minor quantities.

The relative variation between Uv, Gr and An is displayed in Fig. 8, where data for approximately 100 analyses are plotted. The scatter of points in Fig. 8 reflects not only variation between samples, but also inter- and intra-grain variations in garnets from individual samples.

It has been possible to identify four skarn mineral associations for Outokumpu garnets, in each of which the uvarovites have a characteristic chemistry:

1. Large uvarovite crystals enclosed in quartz from a quartz banded diopside sulphide skarn.

2. Small uvarovite crystals, intimately associated with a diopside-pyrrhotite-chalcopyrite skarn.

3. Uvarovite from a fine grained, massive uvarovite rock with diopside, chalcopyrite and pyrrhotite.

4. Vanadian-uvarovite from a chromian tremolite-chromian clinozoisite-pyrrhotite skarn.

The garnets from the first group (Table 8) have moderate $\mathrm{Cr}$ contents, usually $18-19 \%$ (equivalent to $60-63 \% \mathrm{Uv}$ ) and low values of $\mathrm{Fe}, \mathrm{Mg}$, $\mathrm{Mn}$ and $\mathrm{V}$. Individual grains are significantly more compositionally homogeneous than garnets from other associations.

Garnets from the second and third groups (Tables 9. and 10.) are characterised by large 
variations in chemistry, particularly $\mathrm{Cr}, \mathrm{Ca}$ and $\mathrm{Fe}$, both within and between grains. In group 2 there seems to be a tendency for rim compositions to be slightly more enriched in $\mathrm{Fe}$ and $\mathrm{Cr}$ than the cores. The $\mathrm{Cr}$ content of group 2 uvarovites is somewhat lower than that of groups 1 and 3, whilst the Fe content is higher than in any of the other garnet associations at Outokumpu (An as high as $10 \%$ ).

The fourth group of garnets show marked differences in composition when compared with groups 1 to 3 . Whereas in the other groups vanadium is present, but only in minor amounts (usually $<0.5 \% \mathrm{~V}_{2} \mathrm{O}_{3}$ ), in the group 4 garnets the $\mathrm{V}_{2} \mathrm{O}_{3}$ content reaches as high as $2.5 \%$ which recalculates to $8.3 \%$ goldmanite molecule. Significantly the $\mathrm{Cr}_{2} \mathrm{O}_{3}$ content of these garnets (up to $24.6 \%$ equivalent to $81 \% \mathrm{Uv}$ ) is the highest of any of the uvarovites examined for this study.

\section{Chromian diopside and chromian tremolite}

Chromian diopside together with chromian tremolite form the bulk of the chromiferous skarn minerals at Outokumpu. Although the chromium contents of these minerals is relatively low and frequently uneven as compared with other chrome-minerals, the total amount of the minerals is so large, that they carry the bulk of chromium in the whole complex.

In the typical chromiferous skarns, diopside is usually the dominant mineral, accompanied by variable amounts of uvarovite, chromian tremolite, zincian chromite, quartz, calcite, pyrrhotite, chalcopyrite and small amounts of sphalerite and graphite. The diopside is generally coarsegrained, grey to emerald green in colour and frequently zoned. Occasionally, small crystals of gem quality chromian diopside have been found in the ore.

Table 12. Chemical composition and physical properties of chromian diopside and chromian tremolite from Outokumpu.

\begin{tabular}{|c|c|c|c|c|c|}
\hline & 1 & 2 & 3 & 4 & 5 \\
\hline $\mathrm{SiO}_{2}$ & 54.49 & 54.68 & 54.14 & 54.01 & 57.31 \\
\hline $\mathrm{TiO}_{2}$ & 0.04 & 0.04 & 0.04 & 0.05 & 0.05 \\
\hline $\mathrm{Al}_{2} \mathrm{O}_{3}$ & 0.92 & 1.01 & 0.47 & 1.06 & 1.02 \\
\hline $\mathrm{Cr}_{2} \mathrm{O}_{3}$ & 1.09 & 0.42 & 1.02 & 0.71 & 0.55 \\
\hline $\mathrm{Fe}_{2} \mathrm{O}_{3}$ & 0.37 & 0.12 & 0.12 & 0.37 & 0.04 \\
\hline $\mathrm{FeO}$ & 1.51 & 1.26 & 2.22 & 1.37 & 2.47 \\
\hline $\mathrm{MnO}$ & 0.07 & 0.05 & 0.04 & 0.12 & 0.07 \\
\hline $\mathrm{MgO}$ & 16.57 & 16.88 & 16.68 & 16.86 & 22.59 \\
\hline $\mathrm{CaO}$ & 24.62 & 24.77 & 24.82 & 24.94 & 13.63 \\
\hline $\mathrm{Na}_{2} \mathrm{O}$ & 0.37 & 0.26 & 0.40 & 0.44 & 0.13 \\
\hline $\mathrm{K}_{2} \mathrm{O}$ & 0.01 & 0.01 & 0.02 & 0.04 & 0.01 \\
\hline $\mathrm{H}_{2} \mathrm{O}+$ & 0.23 & 0.49 & 0.27 & 0.30 & 2.17 \\
\hline $\mathrm{H}_{2} \mathrm{O}-$ & 0.02 & 0.08 & 0.02 & 0.02 & 0.10 \\
\hline \multirow[t]{2}{*}{$\mathrm{F}$} & - & - & - & - & n.d. \\
\hline & 100.31 & 100.07 & 100.26 & 100.31 & 100.14 \\
\hline D & 3.289 & 3.246 & 3.265 & 3.245 & 2.934 \\
\hline a & - & - & $9.699 \AA$ & $9.718 \AA$ & $9.827 \AA$ \\
\hline$b$ & - & - & 8.932 & 8.922 & 18.137 \\
\hline c & - & - & 5.230 & 5.256 & 5.225 \\
\hline$\beta$ & - & - & $105^{\circ} 57^{\prime}$ & $106^{\circ} 18^{\prime}$ & - \\
\hline$\alpha$ & 1.673 & 1.675 & 1.678 & 1.667 & 1.614 \\
\hline$\beta$ & 1.679 & 1.680 & 1.682 & 1.681 & 1.628 \\
\hline$\gamma$ & 1.698 & 1.698 & 1.701 & 1.700 & 1.638 \\
\hline
\end{tabular}

1. Chromian diopside in uvarovite-pyrrhotite-chalcopyrite ore, analyst Y. L. Tong.

2. Chromian diopside in uvarovite-chromite-sulphide-tremolite skarn, analyst Y. L. Tong.

3. Chromian diopside in quartz, analyst Y. L. Tong.

4. Chromian diopside in chalcopyrite-pyrrhotite ore, analyst Y. L. Tong.

5. Chromian tremolite in diopside-tremolite-calcite skarn, analyst Y. L. Tong. 
There are also some distinct tremolite dominant skarns, closer to the serpentinite contact, often associated with dolomite, carrying minor diopside, uvarovite, zincian chromite and various sulphides. Tremolite is found in coarse, prisms or fibres, of almost white to emerald green colour, some darker varieties are usually associated with uvarovite-chromite skarns.

Table 12. shows the chemical composition of chromian diopsides from various skarn types and of a typical chromian tremolite. Although the diopsides are chemically rather similar, variations are seen in the aluminium, chromium and iron contents. There seems to be a positive correlation between chromium and iron. The chromian tremolite shows a composition which is characteristic of the skarn tremolites of this area.

The wet chemical results also show that the strong, green colour, characteristic of chromian diopside and chromian tremolite is not only due to higher chromium content, but to higher iron as well. Semiquantitative spectrographic analyses of these minerals showed relatively low contents of vanadium, $100-300 \mathrm{ppm} \mathrm{V}$ for chromian diopside and some $110 \mathrm{ppm} \mathrm{V}$ for chromian tremolite.

The microprobe analyses Table 13. of diopside and tremolite inclusions from a large uvarovite crystal are distinctly different from the previous ones. Both chromian diopside and chromian tremolite are richer in chromium and poorer in iron. Compositional zonation in the diopsides indicates an enrichment of aluminium and chromium from core to rim.

\section{Chromian clinozoisite and chromian tourmaline}

These two minerals are found sparingly in some specific skarn mineral associations at $\mathrm{Ou}-$ tokumpu. Chromian tourmaline has been also observed in the Kaavi area some $40 \mathrm{~km}$ northwest of Outokumpu, associated with a chromian muscovite-bearing schist.

In the present study, only the chromian clinozoisite (or tawmawite) will be briefly dealt with, since the chromian tourmalines from Outokumpu and Kaavi have been admirably described by Peltola et al., in 1968.

Chromian epidote was recorded by Eskola (1933) from some remarkable uvarovite-tawmawite-pyrrhotite veins, intersecting the quartzite at the Outokumpu copper mine. Subsequently, chromian epidote was found together with eskolaite and a variety of other chromium minerals and sulphides in some chromian tremolite skarns, from the hanging wall contact of the ore. The present chromian epidote, in the form of a concentrate, was kindly provided by Mr. Vuorelainen of the Outokumpu Company. The min-

Table 13. Microprobe analyses of chromian diopsides and chromian tremolites from Outokumpu.

\begin{tabular}{|c|c|c|c|c|c|c|c|c|}
\hline & 1c & $2 \mathrm{r}$ & 3 & $4 \mathrm{r}$ & 5 & 6 & 7 & 8 \\
\hline $\mathrm{SiO}_{2}$ & 55.64 & 54.77 & 53.88 & 54.20 & 57.35 & 57.95 & 55.90 & 56.29 \\
\hline $\mathrm{TiO}_{2}$ & 0.04 & 0.02 & 0.00 & 0.00 & 0.08 & 0.00 & 0.00 & 0.00 \\
\hline $\mathrm{Al}_{2} \mathrm{O}_{3}$ & 0.06 & 1.30 & 1.12 & 1.16 & 0.97 & 1.74 & 1.71 & 1.73 \\
\hline $\mathrm{Cr}_{2} \mathrm{O}_{3}$ & 0.39 & 1.57 & 1.92 & 2.23 & 0.06 & 0.44 & 1.59 & 1.48 \\
\hline $\mathrm{FeO}$ & 0.33 & 0.33 & 0.39 & 0.26 & 1.75 & 0.57 & 0.49 & 0.61 \\
\hline $\mathrm{MnO}$ & 0.08 & 0.12 & 0.00 & 0.08 & 0.19 & 0.00 & 0.06 & 0.13 \\
\hline $\mathrm{MgO}$ & 17.66 & 17.30 & 16.99 & 16.84 & 22.37 & 23.76 & 23.24 & 22.97 \\
\hline $\mathrm{CaO}$ & 25.58 & 25.12 & 25.24 & 24.94 & 13.84 & 13.61 & 13.50 & 13.79 \\
\hline $\mathrm{Na}_{2} \mathrm{O}$ & 0.23 & 0.33 & 0.24 & 0.37 & 0.47 & 0.52 & 0.59 & 0.00 \\
\hline Total & 100.01 & 100.86 & 99.78 & 100.08 & 97.08 & 98.59 & 97.08 & 97.00 \\
\hline
\end{tabular}

Analyses 1-4, chromian diopside inclusions in a large uvarovite crystal in a large uvarovite crystal in quartz, sp. No. 4884. $\mathrm{c}$ - denotes core, $\mathrm{r}$ - denotes rim.

Analysis 5, chromian tremolite, from uvarovite-chromite skarn, sp. No. 4876.

Analyses 6-8, chromian tremolite inclusions in a large uvarovite crystal in quartz, sp. No. 4884, analyst: E. Condliffe. 
Table 14. Chemical and microprobe analyses of chromian clinozoisite, Outokumpu.

\begin{tabular}{|c|c|c|c|c|c|c|}
\hline & 1 & 2 & 3 & 4 & 5 & 6 \\
\hline $\mathrm{SiO}_{2}$ & 37.87 & 39.26 & 38.78 & 38.23 & 39.01 & 38.42 \\
\hline $\mathrm{TiO}_{2}$ & 0.27 & - & 0.10 & 0.10 & 0.08 & 0.22 \\
\hline $\mathrm{Al}_{2} \mathrm{O}_{3}$ & 27.86 & 24.38 & 29.08 & 28.45 & 28.26 & 26.54 \\
\hline $\mathrm{Cr}_{2} \mathrm{O}_{3}$ & 5.37 & 6.79 & 3.26 & 4.13 & 5.84 & 7.95 \\
\hline $\mathrm{V}_{2} \mathrm{O}_{3}$ & - & - & 0.00 & 0.03 & 0.34 & 0.37 \\
\hline $\mathrm{Fe}_{2} \mathrm{O}_{3}$ & 1.35 & 4.18 & 2.33 & 2.44 & 0.34 & 0.68 \\
\hline $\mathrm{FeO}$ & 0.89 & - & - & - & - & - \\
\hline $\mathrm{MnO}$ & 0.04 & - & 0.00 & 0.00 & 0.00 & 0.04 \\
\hline $\mathrm{MgO}$ & 1.04 & 0.53 & 0.20 & 0.00 & 0.32 & 0.14 \\
\hline $\mathrm{CaO}$ & 23.53 & 20.09 & 23.96 & 24.16 & 23.79 & 23.54 \\
\hline $\mathrm{H}_{2} \mathrm{O}+$ & 2.02 & 4.41 & - & - & - & - \\
\hline $\mathrm{H}_{2} \mathrm{O}-$ & 0.02 & - & - & - & - & - \\
\hline Total & 100.26 & 99.64 & 97.71 & 97.54 & 97.98 & 97.90 \\
\hline$D\left(\mathrm{~g} / \mathrm{cm}^{3}\right)$ & 3.39 & - & & & & \\
\hline a $(\AA)$ & 8.848 & - & & & & \\
\hline b $(\AA)$ & 5.633 & - & & & & \\
\hline c $(\AA)$ & 10.135 & - & & & & \\
\hline$\beta\left({ }^{(}\right)$ & 115.28 & - & & & & \\
\hline
\end{tabular}

1. Chromian clinozoisite, associated with uvarovite, chromian tremolite, pyrrhotite and quartz, analyst: Y. L. Tong.

2. Chromian clinozoisite (tawmawite), in uvarovite, chromian diopside, chromian tremolite, pyrrhotite veins, analyst: P. Eskola.

3-6. Microprobe analyses of chron ian clinozoisite (random grains) from uvarovite, chromian tremolite, pyrrhotite skarn, Outokumpu, analyst: :2. Condliffe.

eral has been analysed by wet chemical- and microprobe methods and the results are shown in Table 14.

The microprobe analyses compare favourably with the chemical analysis. The analysis by Eskola shows rather high contents of iron and water which may be due to an incipient alteration of the mineral or to some impurities.

The chromium content is somewhat variable and iron is, on the whole, so low, that chromian clinozoisite would be a more appropriate name for this mineral. A small, but significant amount of vanadium was noted in analyses $5-6$, which are low in iron. The vanadium content is, however, much lower than in the associated vanadian uvarovite, and it seems that vanadium enters preferentially into the garnet structure.

Peltola et al. (1968) have also noted a significant amount of vanadium in the chromian tourmaline from Outokumpu.

\section{Geochemical considerations}

The most outstanding feature of the Outokumpu skarn mineralization is the abundance and variety of emerald green, chromium-bearing minerals. Moreover, this chromium mineralization is not only confined to the skarns but is seen in the form of accessory minerals in the quartzites and in the massive ores. At Outokumpu, some of the associated quartzites are rich in chromian muscovite (fuchsite), whereas at Luikonlahti, a glassy quartzite carries disseminated uvarovite, indicating high mobility of the migrating, chromiferous solutions during the metamorphic, metasomatic processes of the skarn formation.

Chromium, which is one of the instrumental elements in the skarn mineral formation was introduced from the serpentinites, originally, ultramafic rocks viz., dunites, with some peridotites and pyroxenites, which during the serpentinization process released much of the chromium. Chromite deposits, in general, carry only 
minor amounts of chromium silicates, apart from the ubiquitous chromian clinochlore (kämmererite). Uvarovite has been noted in smaller amounts from a number of chromite deposits of which the layered Bushveld occurrences are perhaps best known. Here, fine-grained, andraditic uvarovite, has formed largely by replacement of chromite in the chromitite seams at the contacts with the noritic rocks, Frankel (1959). The present uvarovites, have crystallized in stages by replacement of zincian chromite, which is one of the commonest accessories in the chromiferous skarns. The relatively low content of iron in the parent chromite is reflected in the uvarovites, which carry only minor amounts of total iron, in contrast to uvarovite associated with chromitites e.g. the Bushveld complex and other localities.

The remarkable zincian chromite appears to have formed under favourable hydrothermal conditions during the early and late stages of skarn formation, when large amounts of chromium and zinc were available.

\section{References}

Borgström, L. H., 1901. Uvarovit från Kuusjärvi. Geol. Fören. Stockholm Förh. 23, 560-563.

Eskola, P., 1933. On the chrome minerals of Outokumpu. Bull. Comm. géol. Finlande 103, 26-44.

Frankel, J. J., 1959. Uvarovite garnet and South African jade (hydrogrossular) from the Bushveld complex, Transvaal. Am. mineral. 41, 565-591.

Gübelin, E. J. \& Weibel, M., 1975. Green vanadium grossular garnet from Lualenyi, near Voi, Kenya. Lapid. J. Inc. San Diego, California.

Haapala, P., 1936. On serpentine rocks in Northern Karelia. Bull. Comm. geol. Finlande 114.

Huhma, A. \& Huhma, M., 1970. Contribution to the geology and geochemistry of Outokumpu region. Bull. Geol. Soc. Finland 42, 57-88.

von Knorring, O., 1951. A new occurrence of uvarovite from northern Karelia in Finland. Min. Mag. 29, 594-601.

Kouvo, O. \& Vuorelainen, Y., 1958. Eskolaite,, a new chro-
The varied composition indicates fluctuations in the chemistry of the mineralizing solutions during successive stages of crystallization.

The presence of vanadium is a characteristic feature of the Outokumpu uvarovites, chromites and other rare, chromium minerals e.g. eskolaite, chromian tourmaline and chromian clinozoisite, including a new vanadian-zincian chromite. According to Peltola et al. (1968), the serpentinites carry from 80 to $160 \mathrm{ppm}_{2} \mathrm{O}_{5}$ and in the associated black schists the tenor of vanadium is much higher, from 900 to $2300 \mathrm{ppm} \mathrm{V}_{2} \mathrm{O}_{5}$, Peltola (1968).

In the course of this study a bright green vanadian uvarovite was observed in a specific skarn association with chromian clinozoisite. This is unusual; vanadium is more commonly found in vanadian-grossular (Gübelin and Weibel 1975), rather than uvarovite.

Acknowledgements. Our thanks to Mrs. Ann Westbrook who prepared the polished samples for microprobe analysis.

mium mineral. Am. Mineral. 43, 1098-1106.

Long, J. V. P.; Vuorelainen, Y. \& Kouvo, O., 1963. Karelianite, a new vanadium mineral. Am. Mineral. 48, $33-41$.

Peltola, E.; Vuorelainen, Y. \& Häkli, T. A., 1968. A chromian tourmaline from Outokumpu, Finland. Bull. Geol. Soc. Finland 40, 35-38.

Peltola, E., 1968. On some geochemical features in the black schists of the Outokumpu area, Finland. Bull. Geol. Soc. Finland 40, 39-50.

Rickwood, P. C., 1968. On recasting analyses of garnet into end-member molecules. Contr. Mineral. and Petrol. 18, 175-198.

Thayer, T. P.; Milton, C.; Dinnin, J. \& Rose, H., 1964. Zincian chromite from Outokumpu, Finland. Am. Mineral 49, 1178-1183.

Tong, Y. L., 1966. The geochemistry of chromium-bearing minerals from nothern Karelia, Finland. M.Sc. Thesis, Dept. of Earth Sciences, Univ. Leeds, U.K.

Vuorelainen, Y.; Häkli, T. A.\& Kataja, M., 1968. A hydrated 
oxide of chromium as a pseudomorph after eskolaite, $\mathrm{Ou}-$ tokumpu. Bull. Geol. Soc. Finland 40, 125-129.

Vähätalo, V. O., 1953. On the geology of the Outokumpu ore deposit in Finland. Bull. Comm. géol. Finlande 164.

Väyrynen, H., 1939. On the geology and tectonics of the Ou- tokumpu ore field and region. Bull. Comm. géol. Finlande 124.

Weiser, T., 1967. Zink-und Vanadium-führende Chromite von Outokumpu Finnland. Neues Jahrb. Miner. Mh. 234-243. Min. Abstr. 20, 225, 1969. 